Jurnal InFestasi

Vol. 12, No.1, Juni 2016

Hal. $98-108$

\title{
PENGARUH PERUBAHAN TARIF PAJAK PENGHASILAN BADAN TERHADAP RETURN SAHAM DENGAN LIABILITAS PAJAK TANGGUHAN SEBAGAI VARIABEL INTERVENING PADA PERUSAHAAN MANUFAKTUR YANG TERDAFTAR DI BEI \\ (Periode 2008 - 2010)
}

\author{
Galih Rhendra Putra \\ Heru Tjaraka \\ galihrhendrap@gmail.com \\ heru_tjaraka@yahoo.co.id
}

\begin{abstract}
This research aimed to test whether there is the effect of changes in corporate income tax rate to return stock with deferred tax liabilities as an intervening variable. Changes in corporate income tax rates expected to have an indirect effect on stock returns.

Variables used in this research include the change in the corporate tax rate as independent variables, stock returns as dependent variable and deferred tax liabilities as an intervening variable. The population used in this research were all manufacturing companies listing on the Stock Exchange in the period the change in corporate income tax rate is 2008-2010. Data were analyzed using path analysis technique to assess causal relationships between variables that have been set.

The results of this research indicate that the phenomenon of corporate income tax rate changes have no significant effect either on the deferred tax liabilities and stock returns, while deferred tax liabilities had a positive effect on stock returns. Results of this research concluded that the deferred tax liabilities can not be a mediator or intervening variable between corporate income tax rate changes and stock returns.
\end{abstract}

Keywords: Tax Rate, Deferred Tax Liabilities and Stock Return

\begin{abstract}
Abstrak
Penelitian ini bertujuan untuk menguji pengaruh perubahan tarif pajak penghasilan badan terhadap return saham dengan utang pajak tangguhan sebagai variabel intervening. Perubahan tarif pajak penghasilan badan diduga memiliki pengaruh tidak langsung terhadap return saham. Variabel penelitian ini adalah perubahan tarif pajak penghasilan badan sebagai independen variabel, return saham sebagai dependen variabel, dan utang pajak tangguhan sebagai variabel intervening. Populasi penelitian yaitu perusahaan manufaktur yang terdaftar di BEI dalam periode perubahan tarif pajak penghasilan badan tahun 2008 - 2010. Analisis data peneltian menggunakan analisis jalur untuk menguji hubungan sebab akibat antar variabel. Hasil penelitian menunjukkan bahwa perubahan tarif pajak penghasilan badan tidak signifikan mempengaruhi retur saham dan utang pajak tangguhan, sedangkan utang pajak tangguhan berpengaruh positif terhadap return saham. Utang pajak tangguhan tidak bisa menjadi variabel intervening antara variabel perubahan tarif pajak penghasilan badan dan retur saham.
\end{abstract}

Kata Kunci : Tarif Pajak, Utang Pajak tangguhan, Return Saham

\section{PENDAHULUAN}

Laporan keuangan perusahaan yang go public sangat penting bagi pengambilan keputusan investasi. Dalam melakukan investasi, laporan keuangan perusahaan sangat berperan penting bagi para calon investor. Karena melalui laporan keuangan, para calon investor dapat mengetahui informasi mengenai kondisi perusahaan yang ingin dipilihnya sebagai objek investasi. Pernyataan Standar Akuntansi Indonesia (PSAK) paragraf 12 (IAI,2012:3) menyatakan 
tujuan laporan keuangan adalah menyediakan informasi yang menyangkut posisi keuangan, kinerja serta perubahan posisi keuangan suatu perusahaan yang bermanfaat bagi sejumlah besar pemakai dalam pengambilan keputusan.

Penyampaian laporan keuangan yang informasinya relevan akan memicu reaksi para pengguna laporan keuangan. Prakoso dan Martani (2012:1) menyatakan bahwa informasi yang relevan adalah informasi yang dapat dijadikan bahan pertimbangan oleh para investor dalam pengambilan setiap keputusan. Ada faktor yang mungkin akan mempengaruhi reaksi pengguna laporan keuangan dalam menilai investasi mereka. Hasil penelitian Sari (2013) menyatakan bahwa perubahan tarif pajak memiliki hubungan tidak langsung terhadap return saham. Hal tersebut memberikan dugaan bahwa ada pengaruh diluar laporan keuangan yang mempengaruhi investor dalam menilai kembali investasi mereka.

Pada tahun 2008, ditetapkan UU No.36 Tahun 2008 Tentang Pajak Penghasilan yang berlaku efektif pada tahun 2009 yang merupakan perubahan ke-4 atas UU No.7 Tahun 1983. Melalui undang-undang ini, Pemerintah memberi kemudahan kepada Wajib Pajak Badan terkait dengan tarif pajak. Salah satu kemudahan yang dimaksud adalah dengan menurunkan tarif pajak penghasilan yang dikenai tarif flat $28 \%$ mulai berlaku pada tahun fiskal 2009 dan menjadi $25 \%$ mulai berlaku efektif pada tahun fiskal 2010 (UU No.36 Tahun 2008). Prakoso dan Martani (2012) menyatakan bahwa penurunan tarif pajak penghasilan badan dapat berpengaruh pada seluruh aktivitas perusahaan salah satunya adalah pada aktivitas yang mempengaruhi pajak tangguhan.

Hubungan antara perubahan undang-undang perpajakan dan pajak tangguhan muncul sebagai topik bahasan baru. Penelitian sebelumnya yang dilakukan pada saat terjadi perubahan undang-undang perpajakan menghasilkan hasil yang positif bahwa informasi pajak tangguhan memiliki relevansi nilai (Amir, dkk. 1997:619).
Pendapat tersebut masih menjadi topik penelitian yang hangat, dimana masih ada penelitian yang dilakukan untuk mendapatkan gambaran terbaru terkait relevansi nilai pajak tangguhan. Amir, dkk. (1997) menyatakan bahwa para investor negara ini berbeda dengan para investor negara maju, para investor negara maju memandang komponen pajak tangguhan memiliki hubungan signifikan dengan harga saham, dalam artian aktiva pajak tangguhan atau kewajiban pajak tangguhan diperlakukan sebagai real assets atau real liability. Menanggapi penelitian yang dilakukan Amir, dkk. (1997), Ayers (1998) dalam Prakoso dan Martini (2012:11) menyatakan bahwa informasi pajak tangguhan akan memiliki relevansi nilai saat terjadinya perubahan undang-undang perpajakan yang signifikan.

Studi yang akan dilakukan oleh peneliti ini kembali mengambil topik terkait pajak tangguhan, dimana dalam penelitian ini peneliti menggunakan liabilitas pajak tangguhan sebagai mediator hubungan tidak langsung antara perubahan tarif pajak penghasilan badan denga return saham. Berangkat dari pemikiran di atas, bahwa ada hubungan tidak langsung antara perubahan $\mathrm{PPh}$ badan dengan return saham, dirumuskan permasalahan dalam penelitian ini adalah: (1) Apakah perubahan tarif pajak penghasilan badan berpengaruh terhadap liabilitas pajak tangguhan?, (2) Apakah liabilitas pajak tangguhan berpengaruh terhadap return saham?, (3) Apakah perubahan tarif pajak penghasilan badan berpengaruh terhadap return saham?, (4) Apakah liabilitas pajak tangguhan bisa dijadikan variabel intervening pengaruh perubahan tarif pajak penghasilan badan terhadap return saham?

Resmi (2003:108) menyatakan bahwa tarif pajak merupakan presentase tertentu yang digunakan untuk menghitung besarnya pajak penghasilan. Tarif pajak penghasilan yang berlaku di Indonesia dikelompokkan menjadi 2 (dua) tarif umum sesuai Pasal 17 UU Nomor 7 tahun 1983 sebagaimana telah diubah 
dalam Undang-undang Nomor 17 Tahun 2000, dan tarif khusus.

Kemudian pada tahun 2008 undang-undang perpajakan tersebut kembali mengalami perubahan dengan ditetapkannya UU Nomor 36 Tahun 2008 yang kembali mengatur tentang tarif pajak penghasilan badan dimana dijelaskan pada pasal 17 ayat 1 (b) yang berbunyi "Wajib Pajak badan dalam negeri dan bentuk usaha tetap adalah sebesar 28\% (dua puluh delapan persen)." Dan pada pasal 17 ayat (2a) kembali menenjelaskan "Tarif sebagaimana dimaksud pada ayat (1) huruf b menjadi 25\% (dua puluh lima persen) yang mulai berlaku efektif pada tahun pajak 2010."

Tabel 1. Tarif Pajak Penghasilan Wajib Pajak Badan Pasal 17 UU No.36 Tahun 2008

\begin{tabular}{|c|c|}
\hline Tahun & Tarif \\
\hline 2009 & $28 \%$ \\
\hline $\begin{array}{l}2010 \text { dan selanjutnya } \\
\text { PT. yang } 40 \% \\
\text { diperdagangkan di } \mathrm{BEI}\end{array}$ & $\begin{array}{l}25 \% \\
5 \% \text { lebih rendah dari yang seharusnya }\end{array}$ \\
\hline $\begin{array}{l}\text { Peredaran bruto sampai dengan Rp. } \\
50.000 .000 .000,00\end{array}$ & $\begin{array}{l}\text { Pengurangan } \\
\text { seharusnya }\end{array}$ \\
\hline
\end{tabular}

Dari penjelasan diatas dapat disimpulkan bahwa dalam rentang tahun 2008-2010 telah terjadi 3 kali perubahan tarif pajak dimana pada tahun 2008 tarif pajak yang berlaku adalah tarif pajak berlapis dengan lapis tertinggi adalah 30\%. Kemudian pada tahun 2009 berlaku tarif pajak tunggal sebesar $28 \%$ dan berubah lagi menjadi tarif tunggal $25 \%$ yang berlaku hingga saat ini.

Waluyo

(2010:231;233) menyatakan bahwa akuntansi pajak penghasilan diatur dalam PSAK 46 dan menggunakan dasar akrual sebagai dasar mengatur ketetapan atas pajak penghasilan yang lebih atau kurang bayar dalam masa pajak dan mengakui kewajiban atau aset pajak tangguhan atas konsekuensi pajak periode yang akan datang, serta penggunaan dasar akrual dalam akuntansi pajak dikarenakan 2 (dua) faktor yaitu: (1) Kepastian peraturan pajak, dan (2) Penggunaan self assessment system sebagai dasar pemungutan pajak atas pajak terutangnya.

Tujuan diterbitkannya PSAK 46 adalah untuk mengatur perlakuan atas akuntansi pajak penghasilan yang meliputi pengakuan, penilaian, penyajian, dan pengungkapan pajak penghasilan serta pengaruhnya karena adanya faktor beda tetap dan beda temporer (waktu). Terdapat 4 (empat) prinsip dasar Akuntansi Pajak Penghasilan dalam PSAK 46 (Waluyo, 2010:232): (1) Konsekuensi pajak periode mendatang yang dapat diatribusikan dengan perbedaan temporer kena pajak (taxable temporary difference) diakui sebagai kewajiban pajak tangguhan, sedangkan efek perbedaan temporer yang boleh dikurangkan (deductable temporary difference) dan sisa kerugian yang belom dikompensasikan diakui sebagai aset pajak tangguhan. (2) Pajak penghasilan yang kurang dibayar tahun berjalan atau terutang diakui sebagai kewajiban pajak kini (current tax liability), sedang pajak penghasilan yang lebih bayar tahun berjalan diakui sebagai aset pajak kini (current tax asset). (3) Pengukuran kewajiban dan aset pajak didasarkan pada peraturan perpajakan yang berlaku, efek perubahan peraturan perpajakan yang akan terjadi di kemudian hari tidak boleh diantisipasi atau diestimasi. (4) Penilaian (kembali) aset pajak tangguhan harus dilakukan pada setiap tanggal neraca, terkait dengan kemungkinan dapat atau tidaknya pemulihan aset pajak 
tangguhan direalisasikan dalam periode mendatang.

Prihantini (2009) menyatakan bahwa return saham adalah tingkat keuntungan yang dinikmati oleh investor untuk investasi yang dilakukannya. Return saham adalah hasil dari investasi surat berharga (saham yang berupa capital gain (loss) yaitu selisih antara harga saham saat ini (closing price pada periode t) dengan harga saham periode sebelumnya (closing price pada periode t-1) dibagi dengan harga saham periode sebelumnya (closing price pada periode t$1)$.

Darmadji \& Fakhruddin (2001:9) menyatakan bahwa ada dua keuntungan (return) yang diperoleh pemodal dengan membeli atau memiliki saham. Keuntungan yang pertama adalah dividen, yaitu pembagian keuntungan yang diberikan perusahaan penerbit saham tersebut atas keuntungan yang dihasilkan perusahaan. umumnya dividen merupakan salah satu daya tarik bagi pemegang saham dengan orientasi jangka panjang seperti misalnya pemodal institusi atau dana pensiun dan lain-lain. Keuntungan yang kedua adalah capital gain, merupakan selisih antara harga beli dan harga jual. Capital Gain terbentuk dengan adanya aktivitas perdagangan saham di pasar sekunder. Dengan adanya perdagangan maka akan timbul perubahan nilai suatu instrumen investasi yang memberikan capital gain.

Dalam penelitian ini, return yang dgunakan adalah cumulative abnormal return. Jogiyanto (2010) mendefinisikan abnormal return sebagai selisih antara actual return dan expected return. Actual return atau return sesungguhnya yang terjadi pada waktu ke-t, merupakan selisih harga saat ini relatif terhadap harga sebelumnya. Expected return merupakan return estimasi yang diharapkan akan diperoleh oleh investor untukmasa yang akan datang yang ditentukan dengan model estimasi. Return realisasi diperoleh dari data harga penutupan (closing price) saham harian. Return ekspektasi dihitung dengan market-adjusted model, yang menggunakan return indeks pasar
(IHSG) pada periode jendela karena pasar modal Indonesia memiliki nilai dan volume transaksi relatif sedikit serta cenderung bergerak hanya pada saat tertentu (Junaedi, 2005:13). Abnormal return akan positif jika return yang didapatkan lebih besar daripada return yang diharapkan. Sedangkan abnormal return bernilai negatif jika return yang didapat lebih kecil dari return yang diharapkan atau return yang dihitung.

Menurut Godfrey dkk. (2010:375) menyatakan bahwa informasi akutansi digunaan untuk menunjukkan bagaimana nilai sebuah persahaan dan klaim tentang hal tersebut akan berubah. Laporan akuntansi digunakan untuk mengawasi atau menegaskan kejadian-kejadian dan transaksi transaksi ekonomi yang telah terjadi. Dalam studi mengenai pasar modal, manajer diasumsikan menyediakan informasi untuk proses pembuatan keputusan yang dilakukan investor. Hipotesis mengenai informasi akuntansi ini berhubungan erat dengan signaling theory, yakni manajer menggunakan akun-akun untuk meng-signal-kan ekspektasi dan tujuan mereka di masa mendatang.

Teori sinyal menjelaskan tentang bagaimana para investor memiliki informasi yang sama tentang prospek perusahaan sebagai manajer perusahaan. namun dalam kenyataannya manajer sering memiliki informasi lebih baik dari investor luar. Hal ini disebut informasi asimetris, dan ini memiliki dampak penting pada struktur modal yang optimal (Brigham, 2005). Asimetri informasi maupun bias informasi dapat terjadi apabila seorang manajer tidak secara lengkap dan benar menyampaikan informasi yang bisa mempengaruhi nilai sebuah perusahaan di pasar modal, sehingga biasanya begitu manajer memberikan informasi kepada pasar sebagai suatu sinyal terhadap adanya peristiwa yang kemungkinan akan mempengaruhi nilai perusahaan, pasar akan merespon dan tercermin pada perubahan harga saham.

Stakeholder Theory mengatakan bahwa perusahaan didirikan tidak beroperasi hanya untuk kepentingan 
sendiri namun harus tetap dapat memberikan manfaat bagi stakeholdernya yaitu pemegang saham, kreditor, konsumen, supplier, pemerintah, masyarakat, analisis dan pihak lainnya (Ghozali dan Chariri, 2007:409). Ghozali dan Chariri (2007:409;411) juga mendefinisikan stakeholder sebagai sebuah kumpulan orang-orang berkepentingan, baik yang berkepentingan secara langsung maupun tidak langsung terhadap eksistensi dan aktivitas perusahaan. Oleh karenanya kelompok ini dengan perusahaan saling mempengaruhi, sebab keberadaan suatu perusahaan sudah tentu dipengaruhi juga oleh dukugan yang berasal dari pada para stakeholder.

Penelitian ini meneliti tentang perubahan tarif pajak penghasilan badan tahun 2008, liabilitas pajak tangguhan, dan return saham. Berdasarkan landasan teori dan kerangka teori diatas, maka dikembangkan hipotesis sebagai berikut:

$\mathrm{H}_{1 \mathrm{~A}}$ : Perubahan tarif pajak penghasilan badan dari tarif progresif ke tarif flat akan berpengaruh secara signifikan pada liabilitas pajak tangguhan

$\mathrm{H}_{1 \mathrm{~B}}$ : Perubahan tarif pajak penghasilan badan ke 25\% akan berpengaruh secara signifikan pada liabilitas pajak tangguhan

$\mathrm{H}_{2}$ : Liabilitas pajak tangguhan akan berpengaruh secara signifikan pada return saham.

$\mathrm{H}_{3 \mathrm{~A}}$ : Perubahan tarif pajak penghasilan badan dari tarif progresif ke tarif flat berpengaruh secara signifikan pada return saham.

$\mathrm{H}_{3 \mathrm{~B}}$ : Perubahan tarif pajak penghasilan badan ke 25\% akan berpengaruh secara signifikan pada return saham.

$\mathrm{H}_{4}$ : Liabilitas pajak tangguhan memediasi / menjadi variabel intervening pengaruh antara perubahan tarif pajak penghasilan badan dan return saham.

Penelitian ini bertujuan untuk mengetahui dan menganalisis pengaruh terjadinya perubahan tarif pajak pengasilan badan tahun 2008, liabilitas pajak tangguhan dan return saham. Dengan harapan diketahui apakah ada pengaruh antara perubahan tarif pajak penghasilan badan dengan liabilitas pajak tangguhan dan pengaruhnya terhadap return saham perusahaan. Berdasarkan tujuan, teori-teori yang melandasi serta penelitian sebelumnya, maka didapat kerangka konseptual seperti gambar berikut

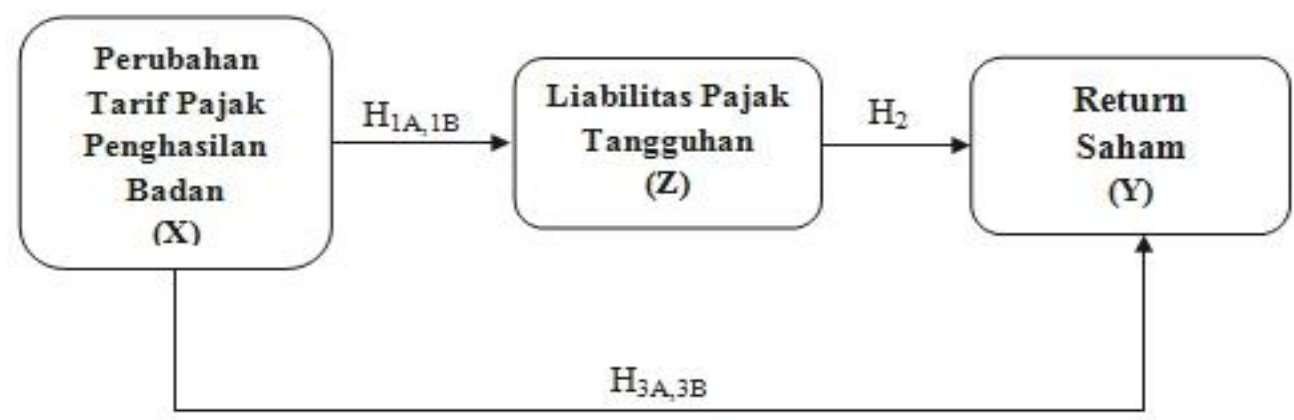

Sumber: data yang diolah Peneliti Gambar 1.1 Kerangka konseptual

\section{METODE PENELITIAN}

Pendekatan yang digunakan dalam penelitian ini adalah pendekatan kuantitatif. Pemilihan pendekatan ini berdasarkan pertimbangan diantaranya variabel penelitian yang dapat teridentifikasi, pengaruh antar variabel dapat diukur, dan kesesuaian dengan rumusan masalah, pengujian hipotesis, mengukur variabel yang sedang diteliti. Teknik analisis yang digunakan dalam 
penelitian ini adalah teknik analisis statistik dengan menggunakan SPSS versi 18. Penelitian ini menggunakan teknik analisis jalur untuk mengetahui hubungan di antara masing-masing variabel. Ghozali (2011) menyatakan bahwa untuk menguji pengaruh variabel intervening digunakan analisis jalur. Analisis jalur itu sendiri adalah perluasan dari analisis regresi berganda untuk menaksir hubungan kausalitas antar variabel yang telah ditetapkan sebelumnya dalam teori. Analisis jalur dalam penelitian ini dilakukan dengan menggunakan metode regresi bertahap.

Dalam penelitian ini menggunakan satu variabel dependen (dependent variable), satu variable independen (independent variable), dan satu variabel intervening. Variabel independen yang terdapat dalam penelitian ini adalah Perubahan Tarif Pajak Penghasilan Badan yang dinotasikan sebagai variabel (X). Variabel dependen dalam penelitian ini adalah return saham (Y). Variabel intervening dalam penelitian ini adalah liabilitas pajak tangguhan yang dinotasikan sebagai variabel $(Z)$.

Populasi penelitian ini adalah perusahaan manufaktur yang terdaftar dalam Bursa Efek Indonesia (BEI) serta mempublikasikan laporan keuangan selama periode 2008-2010. Data yang dipakai dalam penelitian ini adalah data sekunder yang diperoleh langsung dari laporan keuangan auditan perusahaan serta website yahoo finance.

\section{PEMBAHASAN}

Analisis model pada penelitian ini dilakukan dengan menggunakan uji regresi linier berganda. Uji ini dipilih karena bertujuan untuk mengetahui pengaruh variabel bebas, terhadap variabel terikat, serta pengaruh variabel intervening terhadap variabel terikat. Variabel bebas pada penelitian ini adalah perubahan tarif pajak penghasilan badan (X), lalu liabilitas pajak tangguhan (Z) sebagai variabel intervening dan return saham $(\mathrm{Y})$ sebagai variable terikat.

Untuk mengetahui hubungan ketiga variabel penelitian ini, akan diuji enam hipotesis dengan menggunakan analisis jalur sebagai model penelitian. Sebelum dapat mengetahui besarnya pengaruh tidak langsung yang dihasilkan oleh liabilitas pajak tangguhan terhadap hubungan perubahan tarif pajak penghasilan badan dan return saham, dilakukan pengujian pengaruh langsung perubahan tarif pajak penghasilan badan terhadap variabel intervening yaitu liabilitas pajak tangguhan dan variabel dependen yaitu return saham.

Ringkasan mengenai uji hipotesis, baik lintasan yang mempunyai pengaruh signifikan maupun lintasan yang mempunyai pengaruh tidak signifikan adalah sebagai berikut:

Tabel 2. Pengujian Pengaruh Langsung

\begin{tabular}{clccl}
\hline Hipotesis & \multicolumn{1}{c}{$\begin{array}{c}\text { Lintasan } \\
\text { (Path) }\end{array}$} & $\begin{array}{c}\text { Koefisien } \\
\text { (Path) }\end{array}$ & Signifikan & Keterangan \\
\hline $\mathrm{H}_{1 \mathrm{~A}}$ & $\mathrm{X}_{1 \mathrm{~A}} \longrightarrow \mathrm{Z}$ & -0.024 & 0.687 & Tidak signifikan \\
$\mathrm{H}_{1 \mathrm{~B}}$ & $\mathrm{X}_{1 \mathrm{~B}} \longrightarrow \mathrm{Z}$ & 0.068 & 0.244 & Tidak signifikan \\
$\mathrm{H}_{2}$ & $\mathrm{Z} \longrightarrow \mathrm{Y}$ & 0.033 & 0.042 & Signifikan \\
$\mathrm{H}_{3 \mathrm{~A}}$ & $\mathrm{X}_{1 \mathrm{~A}} \longrightarrow \mathrm{Y}$ & 0.006 & 0.597 & Tidak signifikan \\
$\mathrm{H}_{3 \mathrm{~B}}$ & $\mathrm{X}_{1 \mathrm{~B}} \longrightarrow \mathrm{Y}$ & 0.004 & 0.715 & Tidak signifikan \\
\hline
\end{tabular}

Sumber: Output SPSS, diolah 2015.

Setelah diketahui besarnya pengaruh langsung dalam model penelitian ini, akan dihitung pengaruh tidak langsung Perubahan tarif pajak penghasilan badan (X) terhadap return saham (Y) melalui liabilitas pajak tangguhan (Z). Berikut adalah besarnya pengaruh tidak langsung dan pengaruh langsungnya: (1) Besarnya pengaruh tidak langsung = PZ Dum_Tax 1 x PZ Dum_Tax 2 x PY DTL $=-0.024 \times 0.068 \times 0.033=-0.00005386$ dan (2) Besarnya pengaruh langsung = PY Dum_Tax 1 x PY Dum_Tax $2=0.006 \mathrm{x}$ 0.004

$=$

0.00002 
Tabel 3. Pengujian Pengaruh Tidak Langsung

\begin{tabular}{lllll}
\hline Hipotesis & $\begin{array}{c}\text { Lintasan } \\
\text { (Jalur) }\end{array}$ & $\begin{array}{c}\text { Koefisien Jalur } \\
\text { (Pengaruh tidak } \\
\text { langsung) }\end{array}$ & $\begin{array}{c}\text { Koefisien Jalur } \\
\text { (Pengaruh } \\
\text { langsung) }\end{array}$ & $\begin{array}{c}\text { Total } \\
\text { Pengaruh }\end{array}$ \\
\hline $\mathrm{H}_{4}$ & $\mathrm{X} \rightarrow \mathrm{Y} \rightarrow \mathrm{Z}$ & -0.00005386 & 0.00002 & -0.0000338 \\
\hline
\end{tabular}

Sumber: Output SPSS, diolah 2015.

Pengaruh perubahan tarif pajak penghasilan badan dari tarif progresif ke tarif flat $\left(\mathrm{X}_{1 \mathrm{~A}}\right)$ terhadap liabilitas pajak tangguhan $(Z)$ mempunyai koefisien beta sebesar -0.024, menunjukkan bahwa variabel Dum_Tax1 yang memiliki pengaruh negatif terhadap liabilitas pajak tangguhan. Nilai signifikan dari variabel Dum_Tax1 adalah 0.687 lebih besar dari $0.05(\mathrm{a}=5 \%)$, sehingga dapat disimpulkan bahwa variabel Dum_Tax1 berpengaruh negatif dan tidak signifikan pada tingkat $a=5 \%$ terhadap liabilitas pajak tangguhan. Dengan demikian hipotesis pertama penelitian $\left(\mathrm{H}_{1 \mathrm{~A}}\right)$ yang menduga bahwa perubahan tarif pajak dari tarif progresif ke tarif flat berpengaruh signifikan terhadap liabilitas pajak tangguhan ditolak.

Variabel Dum_Tax2 memiliki nilai koefisien sebesar 0.068, yang menunjukkan bahwa variabel Dum_Tax2 memiliki pengaruh positif terhadap liabilitas pajak tangguhan meskipun tidak signifikan. Nilai signifikan sebesar 0.244 diatas $a=5 \%$ menunjukkan bahwa variabel perubahan tarif pajak menjadi tarif flat $25 \%$ tidak berpengaruh secara signifikan terhadap liabilitas pajak tangguhan. Dapat disimpulkan bahwa hipotesis kedua $\left(\mathrm{H}_{1 \mathrm{~B}}\right)$ yang menduga bahwa perubahan tarif pajak menjadi tarif $25 \%$ berpengaruh signifikan terhadap liabilitas pajak tangguhan ditolak.

Pengaruh liabilitas pajak tangguhan $(\mathrm{Z})$ terhadap return saham $(\mathrm{Y})$ mempunyai koefisien beta sebesar 0.033 artinya semakin besar liabilitas pajak tangguhan maka akan meningkat pula return saham yang diterima. Pengaruh tersebut cukup besar karena nilai signifikansi liabilitas pajak tangguhan ke return saham adalah sebesar 0.042, lebih kecil dari $a=5 \%$. Dengan demikian hipotesis ketiga $\left(\mathrm{H}_{2}\right)$ penelitian yang menduga bahwa liabilitas pajak tangguhan berpengaruh signifikan terhadap return saham diterima.

Pengaruh perubahan tarif pajak penghasilan badan dari tarif progresif ke tarif flat $\left(\mathrm{X}_{1 \mathrm{~A}}\right)$ dan pengaruh perubahan tariff pajak penghasilan ke $25 \%\left(\mathrm{X}_{1 \mathrm{~B}}\right)$ terhadap return saham $(\mathrm{Y})$ mempunyai koefisien beta masing-masing sebesar 0.006 dan 0.004, menunjukkan bahwa variabel Dum_Tax1 yang memiliki pengaruh positif terhadap return saham. Namun nilai signifikansi dari variabel Dum_Tax1 adalah 0.597 sedangkan variabel Dum_Tax2 adalah 0.715 , jauh lebih besar dari $0.05(\mathrm{a}=5 \%)$, sehingga dapat disimpulkan bahwa baik variabel Dum_Tax1 maupun Dum_Tax2 berpengaruh positif namun tidak signifikan pada tingkat $a=5 \%$ terhadap return saham. Dengan demikian hipotesis keempat penelitian $\left(\mathrm{H}_{3 \mathrm{~A}}\right)$ yang menduga bahwa perubahan tarif pajak dari tarif progresif ke tarif flat berpengaruh signifikan terhadap return saham ditolak. Begitu pula dengan hipotesis kelima $\left(\mathrm{H}_{3 \mathrm{~B}}\right)$ yang menduga bahwa perubahan tarif pajak menjadi $25 \%$ akan berpengaruh secara signifikan terhadap return saham juga ditolak.

Besarnya pengaruh perubahan tarif pajak penghasilan badan (X) ke liabilitas pajak tangguhan (Z) masing masing adalah sebesar -0.024 untuk Dum_Tax $_{1}$ dan 0.068 untuk Dum_Tax 2 dimana nilai signifikansi perubahan tarif pajak penghasilan badan ke liabilitas pajak tangguhan sebesar 0.687 dan 0.244 , karena signifikansi $>0.05$ maka jalur tersebut tidak signifikan. Akan tetapi, pengaruh liabilitas pajak tangguhan (Z) ke return saham (Y) adalah sebesar 0.033 dengan signifikansi 0.042 yang lebih kecil dari $0.05(<5 \%)$ sehingga jalur tersebut signifikan. Dengan demikian hipotesis ke-enam $\left(\mathrm{H}_{4}\right)$ yang menduga bahwa perubahan tarif pajak penghasilan badan berpengaruh terhadap return saham melalui kinerja keuangan 
perusahaan tidak terbukti, atau $\mathrm{H}_{4}$ ditolak.

Tabel 4. Pembuktian Hipotesis

\begin{tabular}{|c|c|}
\hline Hubungan Antar Variabel Antar Variabel & Hasil \\
\hline $\begin{array}{l}\text { 1. Perubahan tarif pajak dari trif progresif ke tarif flat } \\
\text { terhadap liabilitas pajak tangguhan }\end{array}$ & $\mathrm{H}_{1 \mathrm{~A}}$ Ditolak \\
\hline $\begin{array}{l}\text { 2. Perubahan tarif pajak dari sebelum } 25 \% \text { ke tarif } 25 \% \\
\text { terhadap liabilitas pajak tangguhan }\end{array}$ & $\mathrm{H}_{1 \mathrm{~B}}$ Ditolak \\
\hline 3. Liabilitas pajak tangguhan terhadap return saham & $\mathrm{H}_{2}$ Diterima \\
\hline $\begin{array}{l}\text { 4. Perubahan tarif pajak dari trif progresif ke tarif flat } \\
\text { terhadap return saham }\end{array}$ & $\mathrm{H}_{3 \mathrm{~A}}$ Ditolak \\
\hline $\begin{array}{l}\text { 5. Perubahan tarif pajak dari sebelum } 25 \% \text { ke tarif } 25 \% \\
\text { terhadap return saham }\end{array}$ & $\mathrm{H}_{3 \mathrm{~B}}$ Ditolak \\
\hline $\begin{array}{l}\text { 6. Perubahan tarif pajak ke return saham dengan liabilitas } \\
\text { pajak tangguhan sebagai variabel intervening }\end{array}$ & $\mathrm{H}_{4}$ Ditolak \\
\hline
\end{tabular}

Sumber : data olahan

Fenomena reformasi perpajakan yaitu perubahan tarif pajak penghasilan badan sesuai UU No.36 Tahun 2008 tentang pajak penghasilan yang mengisyaratkan untuk menerapkan tarif tunggal sebesar $28 \%$ yang efektif tahun 2009 dan 25\% yang efektif pada tahun 2010 ternyata tidak berpengaruh terhadap nilai liabilitas pajak tangguhan. Hasil analisis data menunjukkan bahwa pengaruh baik perubahan tarif pajak dari sebelum diterapkannya tarif tunggal dan sesudah diterapkannya tarif tunggal maupun perubahan tarif pajak sebelum $25 \%$ dan sesudah $25 \%$ menunjukkan hasil yang tidak signifikan. Hal ini membuktikan bahwa tidak banyak aktivitas yang dilakukan perusahaan seiring terjadinya fenomena ini yang menyebabkan perubahan nilai liabilitas pajak tangguhan.

Liabilitas pajak tangguhan terbukti memiliki pengaruh yang signifikan terhadap return saham perusahaan. Dengan melihat nilai liabilitas pajak tangguhan, para investor menerima signal dari perusahaan dan merespon informasi tersebut dengan positif. Adanya perubahan niali liabilitas pajak tangguhan, menandakan kemungkinan perusahaan dalam upaya memaksimalkan laba perusahaan. hal itulah yang kemudian direspon positif dalam bentuk meningkatnya return saham perusahaan.

Sama halnya dengan pengaruh perubahan tarif pajak penghasilan badan ke liabilitas pajak tangguhan, perubahan tarif pajak penghasilan badan terhadap return saham juga tidak terbukti adanya pengaruh yang signifikan. Hasil ini membuktikan bahwa return saham perusahaan dalam penelitian ini mendapat pengaruh dari faktor lain diluar penelitian ini.

Dari hasil diatas dapat disimpulkan bahwa liabilitas pajak tangguhan tidak menjadi mediator atau variabel intervening pada perubahan tarif pajak penghasilan badan terhadap return saham. Hal ini dikarenakan pengaruh perubahan tarif pajak penghasilan badan terhadap liabilitas pajak tangguhan tidak signifikan meskipun sebenarnya liailitas pajak tangguhan berpegaruh signifikan terhadap return saham. Hasil ini menunjukkan bahwa investor lebih merespon pergerakan liabilitas pajak tangguhan dibandingkan fenomena perubahan tarif pajak penghasilan badan.

\section{Simpulan}

\section{PENUTUP}

Dari hasil pembahasan, bisa ditarik kesimpulan sebagai berikut:

Perubahan tarif pajak penghasilan terkait tarif tunggal sebesar 28\% yang efektif tahun 2009 dan 25\% yang efektif pada tahun 2010 ternyata tidak berpengaruh terhadap nilai liabilitas pajak tangguhan. (2) Liabilitas pajak tangguhan terbukti memiliki pengaruh yang signifikan terhadap return saham 
perusahaan. (3) Perubahan tarif pajak penghasilan badan terhadap return saham juga tidak terbukti adanya pengaruh yang signifikan. Hasil penelitian ini membuktikan bahwa return saham perusahaan dalam penelitian ini mendapat pengaruh dari faktor lain diluar penelitian ini. (4) liabilitas pajak tangguhan tidak berhasil menjadi mediator atau variabel intervening pada perubahan tarif pajak penghasilan badan terhadap return saham.

\section{Keterbatasan}

Keterbatasan penelitian ini sebagai berikut: (1) Peneliti merasa penggunaan liabilitas pajak tangguhan saja terlalu sempit, sehingg tidak terlalu merepresentasikan perubahan tarif pajak penghasilan badan dibandingkan apabila menggunakan pajak tangguhan secara keseluruhan. (2) Koefisien determinasi yang ditujukan dengan $\mathrm{R}^{2}$ menunjukkan angka yang rendah. Karena itu, penelitian ini masih kurang kongkrit membuktikan argumenargumen teoritis yang telah peneliti paparkan.

\section{Kelemahan}

Penggunaan dummy sebagai pengukuran variabel perubahan tarif pajak penghasilan badan selama periode 2008 hingga 2010 ternyata tidak efektif. Model dummy yang digunakan peneliti dalam penelitian ini masih kurang tepat sehingga didapat hasil yang kurang relevan dengan teori yang ada.

\section{Saran}

Saran yang bisa diberikan dari hasil penelitian ini adalah: (1) Sampel yang dipilih peneliti adalah perusahaan manufaktur dengan berbagai kriteria yang terbatas. Peneliti berharap penelitian selanjutnya bisa menentukan sampel dengan kriteria yang lebih luas maupun periode penelitian yang lebih panjang. Atau penelitian di masa mendatang bisa menggunakan varriabel kontrol ukuran perusahaan supaya didapat hasil yang lebih kuat. (2) Dalam penelitian selanjutnya, diharapkan peneliti tidak hanya menggunakan liabilitas pajak tangguhan namun juga aset pajak tangguhan supaya dapat terlihat mana yang lebih kuat sebagai variabel intervening antara perubahan tarif pajak tangguhan badan terhdap return saham. Dapat juga menggunakan net pajak tangguhan secara keseluruhan tanpa harus memisahkan antara liabilitas maupun aset. Atau faktor lain yang berpengaruh terhadap return saham. (3) Koefisien determinasi yang rendah dalam penelitian ini menunjukkan bahwa penelitian ini belum cukup membuktikan argumenargumen teoritis yang telah dipaparkan. Peneliti berharap penelitian berikutnya mampu memperbaiki segala keterbatasan yang telah diungkapkan dalam penelitian ini maupun sebelumsebelumnya maupun yang belum diungkapkan. (4) Penelitian selanjutnya diharapkan dapat memperbaiki kelemahan yang ada dengan memilih model pengukuran lain untuk variabel perubahan tarif pajak penghasilan badan.

\section{DAFTAR PUSTAKA}

Aditya, N. 2014. Pengaruh Good Corporate Governance Terhadap Return Saham Dengan Kinerja Keuangan Sebagai Variabel Intervening. Airlangga, Surabaya.

Amir, E., et al. 1997. The Valuation of Deferred Taxes. Contemporary Accounting Research, 14(4), 597622.

Ang, R. 1997. Buku Pintar Pasar Modal Indonesia: Mediasoft Indonesia.

Anshori, M., \& S. Iswati. 2009. Metodologi penelitian kuantitatif. Surabaya: Pusat Penerbitan dan Percetakan UNAIR.

Arista, D., \& M. Astohar. 2012. Analisis Faktor-Faktor Yang Mempengaruhi Return Saham (Kasus Pada Perusahaan Manufaktur Yang Go Public Di Bei Periode Tahun 2005-2009). Jurnal Ilmu Manajemen dan Akuntansi Terapan (JIMAT), 3(1).

Ayers, B. C. 1998. Deferred tax accounting under SFAS No. 109: An empirical investigation of its incremental value-relevance 
relative to APB No. 11. Accounting Review, 195-212.

Brigham, E. F. 1995. Introduction to financial management: Harcourt College Pub.

Chen, K. C., \& M. P. Schoderbek. 2000. The 1993 tax rate increase and deferred tax adjustments: A test of functional fixation. Journal of Accounting Research, 23-44.

Chludek, A. K. 2011. Perceived versus actual cash flow implications of deferred taxes-an analysis of value relevance and reversal under IFRS. Journal of International Accounting Research, 1O(1), 1-25.

Darmadji, T., \& H. M. Fakhruddin. 2001. Pasar Modal di Indonesia: Pendekatan Tanya Jawab: Salemba Empat.

Fan, G. 2012. The Effect of Deferred Taxes on Firm Market Value: Evidence from Hong Kong. Hong Kong Baptist University Hong Kong.

Ghozali, I. 2006. Analisis Multivariate Lanjutan Dengan SPSS. Semarang: Badan Penerbit Universitas Diponegoro. .

------. 2011. Aplikasi Analisis Multivariate dengan Program SPSS. Semarang: Badan Penerbit Universitas Diponegoro.

Ghozali, I., \& A. Chariri. 2007. Teori Akuntansi. Semarang: Universitas Diponegoro.

Givoly, D., \& C. Hayn. 1992. The valuation of the deferred tax liability: evidence from the stock market. Accounting Review, 394410.

Godfrey, J., et al. 2010. Accounting theory: John Wiley and Sons.

Hartono, J. 2010. Teori Portofolio dan Analisis Investasi (Vol. 7). Yogyakarta: BPFE.

IAI. 2012. Standar Akuntansi Keuangan: Per 1 Juni 2012.

Juliati. 2013. Kemampuan Deferred Tax Expense Dan Current Tax Expense Dalam Mendeteksi Earnings Management Di Saat Perubahan Tarif Pajak Penghasilan Badan Tahun 2008 - 2010 (Studi Pada Perusahaan Manufaktur Di Bursa
Efek Indonesia). Airlangga, Surabaya.

Lev, B., \& D. Nissim. 2004. Taxable income, future earnings, and equity values. The Accounting Review, 79(4), 1039-1074.

Prakoso, I., \& D. Martani. 2012. Relevansi Nilai Pajak Tangguhan Pada Tahun Terjadinya Perubahan Tarif. Jurnal dan Prosiding SNA Simposium Nasional Akuntansi 15.

Prihantini, R. 2009. Analisis Pengaruh Inflasi, Nilai Tukar, ROA, DER dan CR Terhadap return Saham (Studi Kasus Saham Industri Real Estate and Property yang Terdaftar di Bursa Efek Indonesia Periode 2003-2006). Program Pasca Sarjana Universitas Diponegoro.

Resmi, S. 2003. Teori dan Kasus Perpajakan. Jakarta: Salemba Empat.

Sari, A. N. E. 2013. Pengaruh Perubahan Tarif Pajak Penghasilan Badan Terhadap Return Saham dengan Kinerja Keuangan Sebagai Variabel Intervening. Jurnal Ilmiah Universitas Bakrie, 1(02).

Suharli, M. 2006. Studi Empiris terhadap Dua Faktor yang Mempengaruhi Return Saham pada Industri Food \& Beverages di Bursa Efek Jakarta. Jurnal Akuntansi dan Keuangan, 7(2), pp. 99-116.

Syamsiar, f. 2013. Pengaruh Kepemilikan Institusional, Kepemilikan Manajerial, Kompensasi Manajemen, Dan Perubahan Tarif Pajak Terhadap Penghindaran Pajak Pada Perusahaan Yang Termasuk Kategori Lq-45. Airlangga, Surabaya.

Tanusdjaja, H. 2006. Hubungan pajak tangguhan dengan harga saham, profitabilitas masa depan dan aktivitas manajemen laba. Disertasi. Pascasarjana FE UI, Depok.

Undang-Undang No.36. 2008. Tentang Pajak Penghasilan: Peraturan Menteri Keuangan Republik Indonesia.

Wahyuningsih, D. R. 2007. Hubungan Praktik Manajemen Laba Dengan Reaksi Pasar Atas Pengumuman 
Informasi Laba Perusahaan

Manufaktur Di Bursa Efek Jakarta.

program Pascasarjana Universitas

Diponegoro.

Waluyo, \& Wirawan B. 2010. Perpajakan Indonesia. Jakarta: Salemba Empat.

Widiastuti, N. P. E., \& E. Chusniah. 2011. Analisis Aktiva Pajak Tangguhan Dan Discretionary Accrual Sebagai Prediktor Manajemen Laba Pada Perusahaan Yang Terdaftar Di Bei. EconoSains, IX.

Wijaya, M., \& D. Martani. 2011. Praktik Manajemen Laba Perusahaan Dalam Menanggapi Penurunan Tarif Pajak Sesuai UU No. 36 Tahun 2008. Dalam Simposium Nasional XIV Aceh.

Wiryandari, S. A., \& Yulianti. 2009. Hubungan Perbedaan Laba Akuntansi dan Laba Pajak dengan Perilaku Manajemen Laba dan Persistensi Laba. Simposium Nasional Akuntansi XII, 1-18.

Yulianti. 2005. Kemampuan Beban Pajak Tangguhan Dalam Mendeteksi Manajemen Laba. Jurnal Akuntansi dan Keuangan Indonesia, 2. 